\title{
THE EFFECT OF FINANCIAL AND NON-FINANCIAL SERVICES ON MICRO-ENTREPRENEURS' ECONOMIC PERFORMANCE IN THAILAND: MODERATING EFFECT OF BANK MONITORING
}

\author{
Ruslee Nuh ${ }^{1}$ \\ College of Islamic Studies, Prince of Songkla University, Thailand. \\ (Email: rusleenuh@gmail.com) \\ Muhamed Dahlan bin Ibrahim ${ }^{2}$ \\ Faculty of Entrepreneurship and Business, University Malaysia Kelantan, Malaysia. \\ (Email: dahlan@umk.edu.my) \\ Anis Amira Binti Ab Rahman ${ }^{3}$ \\ Faculty of Entrepreneurship and Business, University Malaysia Kelantan, Malaysia. \\ (Email: anisamira@umk.edu.my)
}

Received date: 18-07-2019

Revised date: 27-08-2019

Accepted date: $29-08-2019$

Published date: 15-09-2019

To cite this document: Nuh, R., Ibrahim, M. D., \& Ab Rahman, A. A. (2019). The Effect of Financial and Non-Financial Services on Micro-Entrepreneurs' Economic Performance in Thailand: Moderating Effects of Bank Monitoring. International Journal of Entrepreneurship and Management Practices, 2 (7), 54-60.

DOI: $10.35631 /$ ijemp. 27007

\begin{abstract}
The purpose of this study is aimed at investigating the effect of financial and nonfinancial services offered by Islamic microfinance on micro-entrepreneurs' economic performance. The study attempts to further examine the moderating effect of bank monitoring in enhancing financial and non-financial services towards micro-entrepreneurs' economic performance. Data were collected from micro-entrepreneurs who involved in Islamic microfinance program in three provinces of Southern border )i.e. Pattani, Yala and Narathiwat (by distributing 480 questionnaires to the selected respondents in the study. Structural Equation Modelling )SEM( using AMOS version 23 was employed to analyze the data and tested the research hypotheses. The result revealed that there was statistically significant effect of both financial and non-financial services on micro-entrepreneurs' economic performance )i.e. increase in outputs, investment and assets(. The study found that financial services had more significant influence on micro-entrepreneurs' economic performance than non-financial services. Interestingly, the result of this study also attested that bank monitoring had moderating effect by enhancing financial and non-financial services on
\end{abstract}


micro - entrepreneurs' economic performance. The implication of these findings was discussed and the recommendations for future research were provided.

Keywords: Financial and Non-Financial Services, Islamic Microfinance, Bank Monitoring, Micro-Entrepreneur'S Economic Performance

\section{Introduction}

Small and Medium Enterprises (SMEs) play significant role in the global economy. It is considered as the backbone of the economy of the countries. According to statistical data regarding the contribution of SMEs towards the GDP growth in Thailand that proved by OSMEP (2017), the contribution of Thai SMEs to GDP was recorded at 42.5 percent of total GPD in 2017. It was expanded by 4.9 percent as compared to the year of 2016 which expanded only 0.1 percent of total SME GDP. The major factors expanded were predominantly tourism, construction, wholesale and retail business, logistic business and transportation. With regards to the increasing number of GDP growth that is accelerated by SMEs in the country, the government thus give the priority to SMEs sector in order to develop their performance. This is related with thai government policy which has established the national strategy policy in 2018 by given the importance of enhancement local economy especially for small enterprises in the country by promoting and establishing rural financial institutions such microfinance institutions in order to develop the entire economy, society and environment of people in the communities (National Strategy, 2018). Thus, microfinance is a tool for enhancing SMEs by providing a small loan or other services in order to improve their performance.

Many microfinance institutions established in Thailand both government and non-government. The main microfinance institutions based on government organizations in Thailand are Bank for Agriculture and Agricultural Cooperatives (BAAC) and Government Savings Bank. Moreover, In Thailand also has launched Islamic microfinance program under Islamic Bank of Thailand (Ibank) that offers the provision of Islamic microfinance schemes based on Shariah compliance (Islamic law) to poor people especially in three provinces of southern border of Thailand and other regions of the country. The purposes of establishing Islamic microfinance are for (1) helping small enterprises out of poverty level. (2) Accelerating and increasing their economic growth and (3) Supporting and improving their quality of life especially for Muslim people in Thailand. Moreover, microfinance has reached poor people globally approximately 34 billion USD in 2018 (Frithjof, 2018) whereas in Thailand are reached around 3,500 million baht. Even though these numbers seem like imposing, they just only a sign of the success of microfinance in reaching the poor. However, the increasing number of disbursing loan to Thai entrepreneurs specially in three provinces of Southern border (Pattani, Yala and Narathiwat) seems to be conversed with the number of collapse in their business where it was proven by the statistical evidence of Non - Performing Loans in Table 1. The Table 1 showed the number of NPLs of Islamic micro finance program during 2010 - 2014 was extremely high, Narathiwat is the highest of NPLs (82.81\%), followed by Pattani (66.9\%) and Yala (63.4\%). 
Table 1: Non - Performing Financing (NPFs) from 2010 - 2014

\begin{tabular}{ccccc}
\hline Provinces & $\begin{array}{c}\text { Clients } \\
\text { (Persons) }\end{array}$ & $\begin{array}{c}\text { Financing } \\
\text { Disbursement } \\
\text { (Million Baht) }\end{array}$ & \multicolumn{2}{c}{ NPFs } \\
\hline Narathiwat & 11,865 & 323.65 & $\begin{array}{c}\text { Clients } \\
\text { (Percentage) }\end{array}$ & $\begin{array}{c}\text { Disbursement } \\
\text { (Percentage) }\end{array}$ \\
Pattani & 5,856 & 320.27 & $(81.86 \%)$ & $(82.81 \%)$ \\
& & & 3,663 & 214.53 \\
Yala & 3,692 & 164.7 & $(62.55 \%)$ & $(66.99 \%)$ \\
& & & $(63.755 \%)$ & 104.53 \\
\end{tabular}

Source: Socio Economic Development in 5 Southern Provinces Department of Islamic Bank of Thailand (2014).

There are several reasons that small enterprises have experienced in failure of their business. For example, many researchers have proved that the main cause of failure in running the business among SMEs is lacking into financial access (Anyanwu, 2003; Carperter, 2001; Lawson, 2007; Ogujiuuba, Fadila, and Stiegler, 2013). This is also found and mentioned in Thai researchers (Subhanij, 2016; Charoenrat, Harvie, and Amornkitvikai, 2013). Besides, small businesses are also lack in access to non-financial services (i.e. training). Mostly in Thailand SMEs fail every year because entrepreneurs basically lack in skills, experience and competency in running their business (Dullayaphut \& Untachai, 2013). This could lead them have less in their performance both in economic and social performance. In fact, the role of microfinance in eradicating the poverty has been still seriously debated in the literature. Previous research studies have found mixed results between positive effect of microfinance (Akpan and Nneji, 2015; Pei-Wen et al., 2016; Alhassan et al., 2016) and negative impacts (Yusuf, Amao, and Olawale, 2014; Sefa, 2014; Samson, Olubunmi, and Adekunle, 2013). However, according to the research studies regarding the effect of microfinance on SMEs performance in Thailand mostly based on conventional microfinance side (Pornwipa and Visit, 2015; Chaiyuth, 2011). There have been scanty empirically found in sort of the impact of Islamic microfinance on SMEs performance. Therefore, it is necessary for this study to fill the literature gap by investigating the effect of Islamic microfinance services (i.e. financial and non-financial services) on micro-entrepreneur's economic performance and further examine the moderating effect of bank monitoring on the relationship between Islamic microfinance services and microentrepreneur's economic performance in Thailand. In this study thus comes up with three main objectives that are stated as below.

1. To investigate the effect of financial services offered by Islamic microfinance on micro - entrepreneurs' economic performance.

2. To examine the effect of non - financial services offered by Islamic microfinance on micro - entrepreneurs' economic performance.

3. To determine bank monitoring has moderating effect on the relationship between Islamic microfinance services and micro entrepreneurs' economic performance. 


\section{Literature Review}

\section{Concept of Islamic Microfinance (IMF)}

Islamic microfinance (IMF) is a choice of financial institution for poor people that its products are relied on Shariah compliance (Islamic law). It is an effective tool for eliminating poverty and appropriate for Muslim and Non - Muslim. The concept of IMF have given by various researchers that referred IMF as significant role in eliminating poverty by proposing the interest free loan to the poor that is called QardHasan or benevolent loan (Alam Choudhury \& Wajdi Dusuki, 2008; Mokhtar, 2011; Mokhtar, Nartea, \& Gan, 2012). In case of Thailand, Islamic microfinance is a program under Islamic bank of Thailand (Ibank). Islamic microfinance program in Thailand currently applies Bai-al Innah model that is a contract of selling and buying. In addition, IMF is provided a small loan to the poor and the clients are able to renew or top up the loan when the previous loan is settled off. Repayment loan is basically on weekly or monthly basis. Furthermore, the loan provided by Islamic microfinance institutions is provided together with compulsory savings or voluntary savings depending on their policy. IMF is more practical tool for poor people that offered the loan without the requirement from collateral or a guarantor (Amran, Rahman, Yusof, and Mohamed (2014)).

\section{Financial Services and SMEs Performance}

Financial service is a provision that offers by microfinance institution such as credit, savings and also other types of financial services such as money transfers, deposit, insurance, and payment services to poor people or low income especially micro-entrepreneurs who normally are difficult in accessing into formal financial institutions (Salim, 2013; Strom, D’Espallier, \& Mersland, 2014; Wagner \& Winkler, 2013). In this study, the financial services are measured in terms of microcredit Access into financial services by micro-entrepreneurs are able to enhance and improve their performance. Many researchers have proven that financial services have positive effect on SME's social performance. For example, Oyedokun (2015) examined the relationship between microfinance funding and small and medium scale entrepreneurial performance in Nigeria. His study found that access to microfinance would lead to enhanced growth and sustainability in businesses. Alhassan, Hoedoafia, and Braimah (2016) that investigated the microcredit on profitability of women owned SMEs in northern Ghana. Their study indicated that there was a significant increase in women SME gross profits over time. Likewise, other researchers also claimed that microfinance services give the significant effect on SMEs performance (Pei-Wen, Zariyawati, Diana-Rose, \& Annuar, 2016; Fredrick \& David, 2015; Kamunge, Njeru, \& Tirimba, 2014; Nur Indah , 2014). On the other hand, some researchers have found that financial services have negative effect on SMEs performance (Yusuf, Amao, and Olawale, 2014; Obasan Kehinde and Soyebo Yusuf, 2013; Sefa, 2014; Samson, Olubunmi, and Adekunle, 2013). However, based on the literature as stated above, the results seem like to have potive effect of financial services on SME's economic performance. Therefore, the hypothesis of this study is postulated as below.

H1: there is positive effect of financial services on micro-entrepreneurs' economic performance. 


\section{Non-Financial Service and SMEs Performance}

Financial services that provide by microfinance institutions are a tool resource for job creation, business enhancement, and livelihood improvement. Notwithstanding, financial services alone are not enough to continuously improve sustainability and livelihood of poor people especially micro-entrepreneurs. Therefore, it should be also integrated of non-financial services and financial services as have been proved and recommended by many researchers. Many researchers have given the meaning of non-financial services as commonly stated that nonfinancial services are referred as skills, training, business advices, marketing assistance, monitoring, technology transfers, and information (Al-Shami et al., 2014; Ellahi, Bukhari, and Naeem, 2010; Committee of Donor Agencies for Small Business Development, 2001). In this study, non-financial services are defined as general management skills and training skills acquisition. Non-financial services are crucial for small business in running their business. The owners of small business those who have skills or received more training are better development of their performance. Theses have been proven by previous researchers for example Logendran (2016) investigated the impact of entrepreneurial training on small enterprise's performance in Sri Lanka. The finding revealed that entrepreneurial training had positive significant impact on small business's performance. Omolo (2015) aimed at researching the influence of training on development of SME performance in Kenya. He found that training contributed to SME performance. But, some researchers argued that training has not significant impact on SME performance for example Duy, Thanh, Oanh, Tam, and Vu (2015), Ojokuku, Sajuyigbe, and Ogunwoye (2014) and Sifunjo (2014). With regards to the significance of non-financial services towards SME's performance, therefore this study attemps to investigate the effect of non-financial services on micro-entreprenuers' economic performance in Thailand. The hypothesis then is presented as following.

H2: there is a positive significant effect of non-financial services on micro-entrepreneurs' economic performance.

\section{Bank Monitoring as Moderating Variable}

Monitoring control is a function of management to control loan default that leads to have serious moral hazard problem (i.e. the client's misused loan) and eventually make the clients have poor in their performance. According to Siaw et al. (2014), monitoring control is able to minimize the problem of unsettle loans by controlling and copping with the clients who utilize their loan for unintended purpose, identifying early warning of any problem regarding to the business operation of the clients that could likely affect the loan performance as well as providing with the covenants of the loan facility and giving the borrowers an opportunity to discuss the problems and prospects of the borrower's business. Monitoring control basically is applied in microfinance as many researchers for example Wesselink (1996) refers monitoring in microfinance as "the routine collection, analysis, and use of information about how well the microfinance institution was going, with the aim of controlling the financial operations and adapting it to circumstances". However, literature studies related the role of monitoring control on performance have been debated. Some studies have claimed that monitoring control has positive effect on performance (Mwangu, 2015; Abdullahi and Muturi, 2016; Ahiabor and Mensah, 2013; Yamuna, 2017) but some researchers proved negative effect of monitoring control on performance (Ejoh and Ejom, 2014; Patterson and Smith, 2007). Base on the inconsistence of the empirical results from previous studies, Baron and Kenny (1986) advised 
that "when there is a weak or inconsistent relation between predictor and criterion variables, then a moderator is required". To fill this gap therefore it is necessary for this study to justify that bank monitoring as moderating variable can moderate the relationship between Islamic microfinance services (financial and non-financial services) and micro - entrepreneurs' economic performance. Thus, the hypothesis of the study is presented as follow.

H3: Bank monitoring has a moderating effect on the relationship between Islamic microfinance services and micro - entrepreneurs' economic performance.

\section{Conceptual Framework}

The conceptual framework of this study tries to examine the effect of financial and nonfinancial services offered by Islamic microfinance on micro-entrepreneurs' economic performance in Thailand. Financial and non-financial services are independent variables while micro-entrepreneur's economic performance is dependent variable. The conceptual framework of the study is included bank monitoring as moderating variable. To support this framework, the conceptualized theory is mainly used by the entrepreneurship process model that was developed by Shane (2003). This theory is utilized to examine the relationship of Islamic microfinance services (financial and non-financial services) and micro-entrepreneurs' economic performance. Shane (2003) describes that small enterprises have an opportunity to acquire the resources (financial and non-financial services offered by Islamic microfinance) in order to enhance their performance (i.e. micro-entrepreneurs' economic performance). Furthermore, asymmetric information theory that generated by Akerlof (1970) is employed as supportive theory in supporting bank monitoring as moderating variable. The theory proposed monitoring to reinforce the relationship between Islamic microfinance services and micro entrepreneur's performance by using internal control as bank monitoring in order to reduce NPLs and enhance their performance. To examine these relationships and supported by the theories as mentioned above, therefore, the framework of this study is presented in Figure 1 as follow.

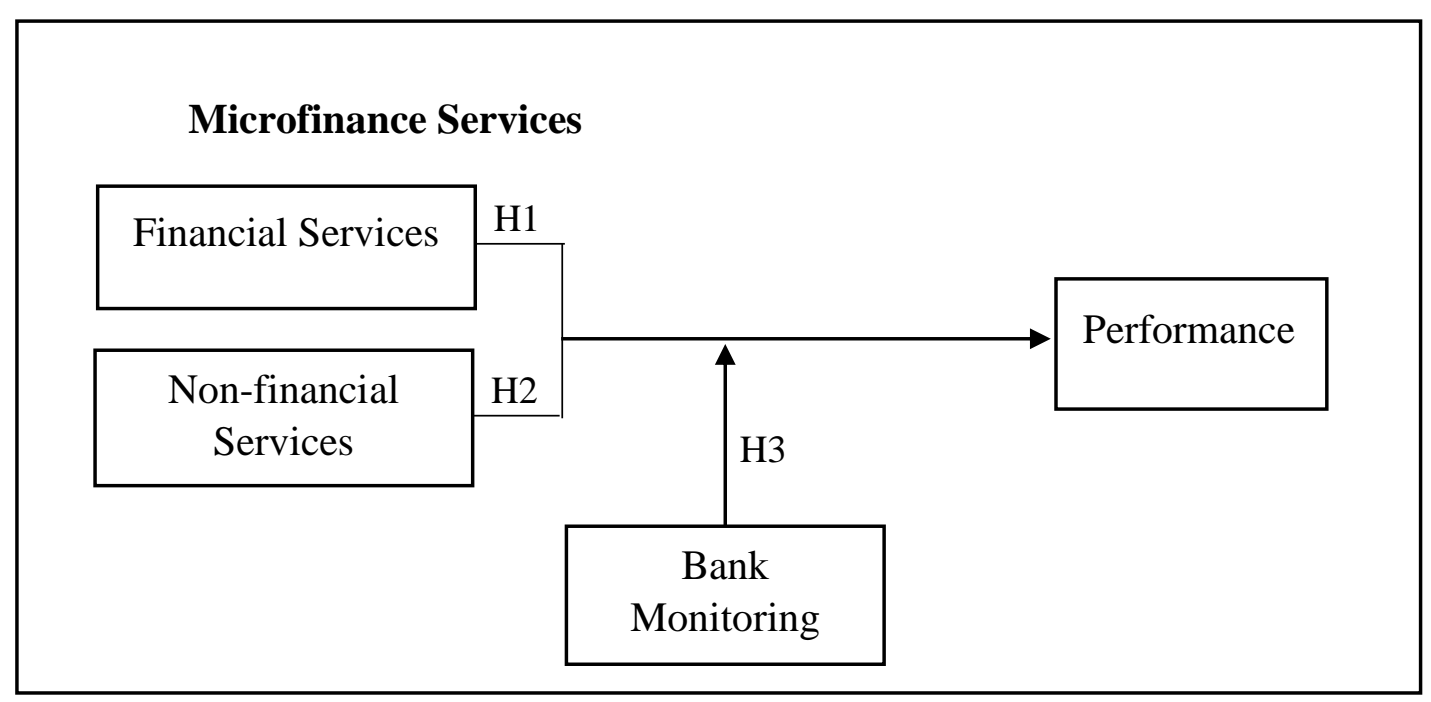

Figure 1: Theoretical Framework 


\section{Methodology}

The unit of analysis in this study is micro-entrepreneurs in three provinces of southern border namely Pattani, Yala, and Narathiwat who have experienced with Islamic microfinance program. This study used quantitative research method and questionnaire was utilized in order to collect the primary data from the field survey. The questionnaire was distributed to selected respondents around 480 cases. Stratified random sampling technique and random sampling were used in this study. The measures in study were financial services, non-financial services, bank monitoring, and micro - entrepreneurs' economic performance. All items of these constructs were measured by seven - point Likert scale from $1=$ strongly disagree to $7=$ strongly agree. All the variables' measurement in this study were adapted from various published studies where financial services and non-financial services are independent variable while micro-entrepreneur's economic performance is dependent variable and bank monitoring is measured as moderating variable. The detail of the variable measurement of the study is depicted in Table 2.

Table 2: The Variable Measurement of The Study

\begin{tabular}{|c|c|c|}
\hline Variables & Sources & No. of Items \\
\hline $\begin{array}{l}\text { Financial services: } \\
\text { - Credit } \\
\text { - Savings }\end{array}$ & $\begin{array}{l}\text { Ekpe (2011), Yeboah (2010) } \\
\text { and Tiruneh (2006). } \\
\text { Ekpe (2011), Tiruneh (2006) } \\
\text { and Simeyo et al. (2011). }\end{array}$ & 10 \\
\hline $\begin{array}{cl}\text { Non-financial services: } \\
\text { - } & \text { Training skills } \\
& \text { acquisition (TSA) } \\
\text { - } & \text { General management } \\
& \text { skills (GMS) }\end{array}$ & $\begin{array}{l}\text { Ekpe (2011) } \\
\text { Ekpe (2011), Musyoki } \\
(2011) \text { and Simeyo et al. } \\
(2011)\end{array}$ & $\begin{array}{l}4 \\
11\end{array}$ \\
\hline Bank monitoring & $\begin{array}{l}\text { Musyoki (2011), Siaw et al. } \\
\text { (2014), Norell (2001) and } \\
\text { Kakuru (2008). }\end{array}$ & 18 \\
\hline Economic performance & $\begin{array}{l}\text { Ekpe (2011), Yeboah (2010) } \\
\text { and Tiruneh (2006). }\end{array}$ & 16 \\
\hline
\end{tabular}

The data analysis in this study utilized Structural equation modelling (SEM) by using AMOS software version 23 to analyse the hypotheses in the study. SEM was suitable with this study because it is able to test complicated model by testing the relationship between observed and unobserved variables and also test the relationship between two or more latent variables simultaneously (Hair, Black, Babin, \& Anderson, 2010). Moreover, SEM represents the powerful and rigid statistical techniques to deal with complex models (Byrne, 2001; Hair, Black, Babin, Anderson, \& Tatham, 2006; Tabachnick \& Fidell, 2001). Furthermore, the study tested confirmation factor analysis (CFA) to confirm validity of the model before proceed SEM analysis. 
Furthermore, the result of non-financial services also indicated positive effect on microentrepreneurs' economic performance that is $(\beta=0.282$; $C R=5.637 ; p<0.000)$. Therefore, hypothesis 2 (H2) is supported. This result is in tandem with the previous research (Duy, Thanh, Oanh, Tam, and Vu, 2015; Ojokuku, Sajuyigbe, and Ogunwoye, 2014; and Sifunjo, 2014). Interestingly, based on the empirical result of the study, it has been found that financial services were more effect than non-financial services on micro-entrepreneurs' economic performance. This can be meant that micro-entrepreneurs in three provinces of southern border of Thailand were influenced in improving their economic performance (outputs, investment and assets) by receiving financial services from Islamic microfinance.

\section{Moderating Analysis Result}

The result of moderating effect of bank monitoring on the relationship between Islamic microfinance services (financial and non-financial services) and micro - entrepreneurs' economic performance is shown in Table 5 as below.

\section{Table 5: Test of Moderating Effect}

\begin{tabular}{lllllll}
\hline Relationship & Moderator & Constrained & $\begin{array}{l}\text { Un- } \\
\text { constrained }\end{array}$ & $\begin{array}{l}\text { Chi }- \\
\text { Square } \\
\text { difference }\end{array}$ & $\begin{array}{l}\text { Result on } \\
\text { moderation }\end{array}$ & $\begin{array}{l}\text { Result on } \\
\text { hypothesis }\end{array}$ \\
\hline EP < -- FS & $\begin{array}{l}\text { High bank } \\
\text { monitoring }\end{array}$ & 35.580 & 13.448 & 22.132 & Significant & Supported \\
\cline { 2 - 7 } & $\begin{array}{l}\text { Low bank } \\
\text { monitoring }\end{array}$ & 64.013 & 25.328 & 38.685 & Significant & Supported \\
\hline EP < -- NFS & $\begin{array}{l}\text { High bank } \\
\text { monitoring }\end{array}$ & 48.033 & 13.448 & 34.585 & Significant & Supported \\
\hline & $\begin{array}{l}\text { Low bank } \\
\text { monitoring }\end{array}$ & 101.704 & 25.328 & 76.376 & Significant & Supported \\
\hline
\end{tabular}

Based on the Table 5, the moderating effect for bank monitoring is significant since the difference in chi - square value between constrained and unconstrained model for high and low group is greater than 3.84 (Zainudin, 2014). For the moderating effect of bank monitoring on the relationship between financial services and micro-entrepreneurs' economic performance, the result indicated that bank monitoring moderated and influenced the relationship between financial services and micro-entrepreneurs' economic performance whereby both high and low of bank monitoring model were significant when the difference in chi-square values of constrained and unconstrained model were 22.132 and 38.685, respectively. While the relationship between non-financial services and micro-entrepreneurs' economic performance was also moderated by bank monitoring when the difference in chi-square values of constrained and unconstrained model for both high and low bank monitoring that were 34.585 and 76.376, respectively. Moreover, the moderating effect of bank monitoring was able to enhance the relationship of financial and non-financial services towards micro-entrepreneurs' economic performance and influenced as partial moderation since both high and low model were both significant (see Table 6). 
Table 6: Standardized beta estimate for High and Low Internal Control Group

\begin{tabular}{llllll}
\hline Relationship & Moderator & $\begin{array}{l}\text { Standardized } \\
\text { beta estimate }\end{array}$ & P & Result & $\begin{array}{l}\text { Type of } \\
\text { Moderation }\end{array}$ \\
\hline EP < --- FS & $\begin{array}{l}\text { High bank } \\
\text { monitoring }\end{array}$ & 0.426 & 0.000 & $\begin{array}{l}\text { Significant } \\
\text { at } 0.05\end{array}$ & $\begin{array}{l}\text { Partial } \\
\text { Moderation }\end{array}$ \\
\hline $\begin{array}{l}\text { Low bank } \\
\text { monitoring }\end{array}$ & 0.493 & 0.000 & $\begin{array}{l}\text { Significant } \\
\text { at } 0.05\end{array}$ & \\
\hline EP < --- NFS & $\begin{array}{l}\text { High bank } \\
\text { monitoring }\end{array}$ & 0.307 & 0.000 & $\begin{array}{l}\text { Significant } \\
\text { at } 0.05\end{array}$ & Partial \\
& $\begin{array}{l}\text { Low bank } \\
\text { monitoring }\end{array}$ & 0.244 & 0.000 & $\begin{array}{l}\text { Significant } \\
\text { at } 0.05\end{array}$ & \\
\hline
\end{tabular}

Therefore, the hypothesis 3 (H3) in this study is supported. This result is able to fill the literature gap as suggested by Baron and Kenny (1986) by justifying that bank monitoring moderated the causal effect of Islamic microfinance services (both financial and non-financial services) on micro - entrepreneurs' economic performance. Moreover, the result of this study is capable to support the asymmetric information theory and can contribute to the body of knowledge in terms of employing this theory to mitigate the problem of high NPLs by using bank monitoring as a mechanism to solve this problem and lead micro - entrepreneurs in three provinces of southern border are able to manage their loan in order to avoid misused loan and improve their performance with better life.

\section{Conclusion}

In summary, the study proved that financial and non-financial services offered by Islamic microfinance program were significant effect on micro-entrepreneurs' economic performance. All factors of Islamic microfinance services were indicated to be strong predictors, especially financial services, to improve micro - entrepreneurs' economic performance in three provinces of southern border of Thailand (i.e. Pattani, Yala, and Narathiwat) by improving their outputs, investment and assets. More interestingly, the finding has justified that bank monitoring provided by Islamic microfinance could moderate and influence the relationship of financial and non-financial towards micro-entrepreneurs' economic performance. In addition, the result of testing moderating effect of bank monitoring could support the asymmetric information theory by confirm that utilizing of bank monitoring could control unsettled loan of the customers and lead to improve their economic performance. As consequence, the findings would suggest to Islamic microfinance institutions or other relevant stakeholders to provide more Islamic microfinance products especially financial services such as reasonable credit, more savings schemes, and Islamic Takaful. Moreover, the policy makers should take more consideration on non-financial services by providing continuously training to the customers in order to improve their skills of doing business that lead them to have better in their performance. Moreover, Islamic microfinance or policy makers should act seriously and strictly in monitoring the customers in order to control their loan that could decrease NPLs and improve their performance.

Furthermore, the limitation of this study is just focused in the areas of three provinces of southern border. Therefore, it could be suggested for the future research by examining the effect 
of financial and non-financial services on micro - entrepreneurs' economic performance to other regions and compare their performance in each region.

\section{Reference}

Abdullahi, M. H., \& Muturi, W. (2016). Effect of Internal Control Systems on Finacial Performance of Higher Education Institutions in Puntland. International Journal of Economics, Commerce and Management, 4(12).

Ahiabor, G., \& Mensah, C. C. Y. (2013). Efectiveness of Internal Control on the Finances of Churches in Greater Accra, Ghana. Research Journal of Finance and Accounting, 4(13), 115-120.

Akerlof, G. A. (1970). The market for" lemons": Quality uncertainty and the market mechanism. The quarterly journal of economics, 488-500.

Akpan, E. S., \& Nneji, I. D. (2015). Contribution of Microfinance Banks to the Development of Small and Medium Scale Enterprises in Nigeria. Research Journal of Finance and Accounting, 6(8), 19-28.

Alhassan, E. A., Hoedoafia, M. A., \& Braimah, I. (2016). The Effects of Microcredit on Profitability and the Challenges on Women Owned SMEs: Evidence from Northern Ghana. Journal of Entrepreneurship and Business Innovation, 3(1), 29-47.

Anyanwu, C. M. (2003). The role of cbn of nigeria in enterprises financing, paper delivered at Small and Medium Industries Equity Investment Scheme (SMIEIS) Seminar. CBN Training Centre, Lagos.

Baron, R. M., \& Kenny, D. A. (1986). The moderator-mediator variable distinction in social psychological research: Conceptual, strategic, and statistical considerations. Journal of personality and social psychology, 51(6), 1173.

Byrne, B. M. (2001). Structural Equation Modelling with Amos: Basic Concepts, Applications, and Programming: Mahwah, NJ: Erlbaum.

Carperter, C. (2001). Making small business finance profitable in Nigeria SME finance in Nigeria. Retrieved on 18th March. 2007 from the website: www.nipc-ng.org.

Charoenrat, T., Harvie, C., \& Amornkitvikai, Y. (2013). Thai manufacturing small and medium sized enterprise technical efficiency: evidence from firm-level industrial census data. Journal of Asian Economics, 27, 42-56.

Committee of Donor Agencies for Small Business Development. (2001). Guiding Principles for Donor Intervention (2001 ed.). Washington-USA. Business Development Services For Small Enterprises: Guiding Principles For Donor Intervention (2001 ed.) Washington-USA.

Ejoh, N., \& Ejom, P. (2014). The impact of internal control activities on financial performance of tertiary institutions in Nigeria. Journal of Economics and Sustainable Development, 5(16), 133-143.

Ellahi, N., Bukhari, T. A., \& Naeem, M. (2010). Role of Islamic Modes of Financing for Growth of SMEs A Case Study of Islamabad City. International journal of academic research, 2(6).

Fredrick, M. K., \& David, M. O. (2015). Effects of Microfinance Institutions' Products on Financial Performance of Small and Medium Enterprises; A Case of Machakos Town, Kenya. Journal of Business and Management, 17(4), 50-57.

Frithjof, A. (2018). The 34 Billion Dollar Question: Is Microfinance the Answer to Poverty? The Conversation. $\quad$ Retrieved July 2018. 
https://www.weforum.org/agenda/2018/01/the-34-billion-dollar-question-ismicrofinance-the-answer-to-poverty

Ghalib, A. K., Malki, I., \& Imai, K. S. (2015). Microfinance and household poverty reduction: Empirical evidence from rural Pakistan. Oxford Development Studies, 43(1), 84-104.

Hair, J. F., Black, W. C., Babin, B. J., \& Anderson, R. E. (2010). Multivariate Data Analysis. Seventh Edition. : Prentice Hall, Upper Saddle River, New Jersey.

Hair, J. F., Black, W. C., Babin, B. J., Anderson, R. E., \& Tatham, R. L. (2006). Multivariate data analysis (Vol. 6): Pearson Prentice Hall Upper Saddle River, NJ.

Kamunge, M. S., Njeru, A., \& Tirimba, O. I. (2014). Factors affecting the performance of small and micro enterprises in Limuru Town Market of Kiambu County, Kenya. International Journal of Scientific and Research Publications, 4(12), 1-20.

Lawson, B. (2007). Access to finance for SMEs, Financial System Strategy 2020, . Paper presented at the International Conference, Abuja. http://www.cenbank.org/fss/mon/FSS2020Presentation\%20at\%20International\%20Co nference.ppt.

Logendran, M. (2016). Impact of Entrepreneurship Training on Performance of Small Enterprises in Jaffna District. Global Journal of Commerce and Management Perspectives, 5(2), 1-6.

Mwangu, A. W. (2015). How Monitoring and Evaluation Affects the Outcome of Constituency Development Fund Projects in Kenya: A Case Study of Projects in Gatanga Constituency. International Journal of Academic Research in Business and Social Sciences, 5(3), 13.

National Strategy (2018). National Stratey within 20 years report (B.E 2060-2536).

Nur Indah, R. (2014). Exploring the Role of Islamic Microfinance Institution in Poverty Alleviation Through Microenterprises Development, A Case Study of Islamic Financial Cooperative (BMT) in Indonesia. Kyoto Bulletin of Islamic Area Studies, 7, 49-66.

Ogujiuba, K., Fadila, J., \& Stiegler, N. (2013). Challenges of Microfinance Access in Nigeria: Implications for Entrepreneurship Development. Mediterranean Journal of Social Sciences, 4(6).

Ojokuku, R., Sajuyigbe, A., \& Ogunwoye, A. (2014). Human resource management practices and small-scale business performance: Evidence from Osun State, South Western Nigeria. Journal of Emerging Trends in Economics and Management Sciences, 5(7), 1.

Omolo, R. D. J. W. (2015). Training and Development on Performance of Small and Medium Enterprises in Kisumu County, Kenya. International Journal, 26.

Oyedokun, A. J. (2015). Entrepreneurial Firms and Microfinance Funding in Southern Nigeria International Journal of Research in Business Management, 3(10), 67-76.

Patterson, E. R., \& Smith, J. R. (2007). The effects of Sarbanes-Oxley on auditing and internal control strength. The Accounting Review, 82(2), 427-455.

Pei-Wen, T., Zariyawati, M., Diana-Rose, F., \& Annuar, M. (2016). Impact of Microfinance Facilities on Performance of Small Medium Enterprises in Malaysia. World Applied Sciences Journal, 34(12), 1845-1849.

Pornwipa, P. \& Visit, L. (2015). Influence of Agricultural Credit on Farmer Housewife Empowerment. Kasetsart J. (Soc-Sci), 36, 448-464.

Salim, M. M. (2013). Revealed objective functions of Microfinance Institutions: Evidence from Bangladesh. Journal of Development Economics, 104, 34-55. 
Samson, A. Y., Olubunmi, A. B., \& Adekunle, O. A. (2013). Microfinance Bank as a Catalyst for Entrepreneurship Development in Nigeria: Evidence from Ogun State. International Journal of Business and Social Science, 4(12).

Sefa, K. A. (2014). Impact of Microfinance Interventions: A Meta-analysis. Disscussion Paper $03 / 14$.

Shane, S. A. (2003). A general theory of entrepreneurship: The individual-opportunity nexus: Edward Elgar Publishing.

Siaw, A., Ntiamoah, E. B., Oteng, E., \& Opoku, B. (2014). An Empirical Analysis of the Loan Default Rate of Microfinance Institutions. European Journal of Business and Management, 6(22), 12-17.

Sifunjo, E. K., Naomi, M. Mwewa. (2014). Effects of Micro-credit, Micro-savings and Training on the Growth of Small and Medium Enterprises in MachakosCounty in Kenya. Research Journal of Finance and Accounting, 5(7).

Strom, R. O., D’Espallier, B., \& Mersland, R. (2014). Female leadership, performance, and governance in microfinance institutions. Journal of Banking \& Finance, 42, 60-75.

Subhanij, T. (2016). Commercial Bank Innovations in Small and Medium-Sized Enterprise Finance: Global Models and Implications for Thailand.

Tabachnick, B. G., \& Fidell, L. S. (2001). Using multivariate statistics.

Wagner, C., \& Winkler, A. (2013). The vulnerability of microfinance to financial turmoilevidence from the global financial crisis. World Development, 51, 71-90.

Yamuna, R. P. (2017). An Empirical Study of Factors that Determines the Effectiveness of Internal Control System on Operational Performance in SMEs in Malaysia. International Journal of Science Arts and Commerce, 2(3).

Yusuf, S. A., Amao, J. O., \& Olawale, O. T. (2014). Effects of Microcredit on Small Scale Enterprises in Osun State, Nigeria. American International Journal of Contemporary Research, 4(6).

Zainudin, A. (2014). Research Methodology and Data Analysis. Shah Alam: University Teknologi MARA Publication Centre (UITM Press). 